\title{
Strategies in Learning and Techniques in Teaching English Speaking
}

\author{
Leffi Noviyenty \\ Institut Agama Islam Negeri (IAIN) Curup \\ Iffel_me@yahoo.co.id
}

\begin{abstract}
Learning how to speak English fluently and accurately is always a grand task for foreign students. Strategies in learning to speak as one of important factors of speaking skill should be considered not only by foreign students but also the teachers. Students' strategies in learning to speak English should be in balance with teachers' techniques in teaching students to speak English. Both affect the improvement of students' ability in speaking English. This research is descriptive which tries to describe and elaborate the students of SMAN 1 Curup's strategies in learning to speak English and their English techniques in teaching them to speak. There were 47 third year students selected as the sample from 8 classes and 7 English teachers. The instruments used in this study were questionnaire which were given both to the students and teachers with different items and also interview guidance. The findings showed that the strategies used by SMAN 1 Curup's students in learning to speak English were classified into metacognitive strategies, cognitive strategies, social strategies, and affective strategies. The English teacher techniques in teaching student were roleplay, group presentation, group discussion, speech competition, dialogues, direct correction, speaking in group, debate competition, games, and listening song.
\end{abstract}

Keyword : Students' Strategies, Speaking, Teachers' Techniques

\section{INTRODUCTION}

Learning how to speak English fluently and accurately is always a grand task for foreign English students. Due the significance of interaction between the teacher and the students at senior high school, speaking competence can hardly be overvalued. Lack of speaking competence prohibits the opportunities for students to interact with the teachers and peers in the classroom. Furthermore, there are many factors that influence the successful of teaching and learning speaking,

\author{
ENGLISH FRANCA : Academic Journal of English Language and Education \\ Vol. 2, No. 1, 2018, STAIN Curup \\ P-ISSN 2580-3670, E-ISSN 2580-3689
}


such as students' learning strategies and teachers' techniques in teaching students to speak English. The primary function of spoken language is interactional, to establish and maintain social relation (Brown and Yule, 1983). However, an important function of spoken language is primarily transactional - to convey information. There is a three-dimension grid for speaking and oral interaction, one dimension relating to the interactional contexts, another relating to the different functions which can be performed in these contexts, and the third relating to the management of interaction and negotiation of meaning (Nunan, 2000). Nunan also suggests that the most interaction interactions can be placed on a continuum from relatively predictable to relatively unpredictable. Predictability will depend on a range of factors such as language itself, context of situation, including the interlocutors and their relationships, the topic of conversation and soon.

Strategies in learning to speak English are one of the important factors to be recognized by students and it is also a part of speaking skill. These strategies should be developed in order to improve the students' ability in speaking English. The students should be able to recognize their weaknesses and their strength in choosing the suitable strategies for themselves. Each student is possible to have different strategy one to another. The strategies used by the students in learning to speak English will determine their ability in using English to communicate. Students who use effective strategies which make them comfortable in using English to communicate will be able to solve many problems in speaking English.

Learning strategy is specific actions, behaviors, steps, or techniques such as seeking out conversation pattern, or giving oneself encouragement to tackle a difficulty language task used by the students to enhance their own learning (Murcia, 2001)

Learning strategies are task specific tactics or techniques, observable or no observable that an individual uses to comprehend, store, retrieve and use information or to plan, regulate, or assess learning (Hardley, 2001). The performance of this strategies could possibly be observed.

Another important factor which also influences the students' ability in learning to speak English is teachers' techniques in teaching students to speak English. A professional English teacher should consider appropriate strategies in teaching speaking. He must recognize his students' strategies and help them to develop their strength in order 
to improve his students' oral production. It requires not only the ability to create a warm and humanistic classroom atmosphere, but also provides opportunities for his students to speak or take part in class interaction.

SMAN 1 Curup as one of the favorite state high school in Curup Town has a lot of active students in speaking English. It can be seen from many English Contest that the school followed and they always in a top rank. For example, English speech contest, English Debate, English Quiz and many other English contests which influence oral skill of English. Since speaking or ability to use English to communicate is a part of the purpose of teaching English and one component of communicative competence in Competence-Based Curriculum, it is important to always develop the ways in learning and teaching speaking. Based on this reason, it is interested to investigate the ways the students of SMA 1 Curup's learning strategies to speak English and also the role of their teachers in helping them to speak English well. This study tries to elaborate and describe the students' strategies in learning to speak English and their English teachers' techniques in teaching them to speak English.

\section{Research Questions}

This study tries to elaborate and describe the students' strategies in learning to speak English and their English teachers' techniques in teaching them to speak English. The research questions are presented as follow:

1. What are the strategies used by students of SMAN 1 Curup in learning to speak English fluently?

2. What are the techniques used by English teachers of SMAN 1 Curup in teaching English speaking?

\section{Purposes of the Research}

The purposes of this research are to investigate:

1. The strategies used by the students of SMAN 1 Curup in learning to speak English fluently.

2. The techniques used by English teachers of SMAN 1 Curup in teaching English speaking.

\section{Definition of Key Terms}


In order to avoid misunderstanding, the researcher defines specific key terms aas follow:

1. Speaking Strategies are strategies used by the students in learning to speak English in the class and outclass, which are categorized into three kinds: metacognitive, cognitive and social/affective strategies.

2. Teaching techniques are techniques used by English teachers in teaching their students to speak English during the process of teaching and learning in the classroom.

\section{Speaking Strategies and Good Language Learner Strategies}

It is important for students to recognize their own weaknesses and strength in learning, particularly learning a language. An ability to select and use suitable strategies in learning to speak English will help them build their ability to speak English easier and faster. O' Malley and Chamot divides learning strategies into three types: Metacognitive strategies, cognitive strategies and social/affective strategies (Chammot, 1999). Metacognitive strategies deal with mental operations used by learners in the self-management of their learning which cover planning, directed attention, selective attention, self-management, selfmonitoring, problem identification and self-evaluation. Cognitive Strategies involve the direct analysis and manipulation of language input which cover repetition, resourcing, deduction and inferencing. While Social/affective Strategies concern about interaction with other learners and management of the affective demands made by language learning, such as cooperation, questioning for clarification, self-talk.

The successful of learning to speak English, especially for the learners who learn English s foreign language, is influenced by several factors. Two of them are knowledge about strategies in learning to speak and the students' ability to select the appropriate strategies for themselves. The successful in mastering these two aspects will bring the students to be good language learners. Rubin and Thomson (Nunan, 1996) characterize the good language learner strategies as follow:

1. Good learners find their own way

2. Good learners organize information about the language

3. Good learners are creative and experiment with the language 
4. Good learners make their own opportunities and find strategies for setting practice in using the language inside and outside the classroom

5. Good learners learn to live with uncertainty and develop strategies for making sense of the target language without wanting to understand every word

6. Good learners use mnemonics (rhymes, word association, etc) to recall what has been learned

7. Good learners make error work

8. Good learner use linguistic knowledge, including knowledge oft heir first language in mastering a second/foreign language

9. Good learners let the context (extra linguistic knowledge and knowledge of the world) help them in comprehension

10. Good learners learn to make intelligent guesses

11. Good learners learn chunks of language as a whole and formalized routines to help them perform beyond their competence

12. Good learners learn production techniques (e.g. techniques for keeping a conversation going)

13. Good learners learn different styles of speech and writing and learn to vary their language according to the formality of the situation.

In addition, Oxford in Benson (Benson, 2001) lists some strategies for language learners as follow:

1. Social Strategies

a. Asking questions:

- Asking for clarification or verification

- Asking for correction

b. Cooperating wit others:

- Cooperating with peers

- Cooperating with proficient users of the new language

c. Empathizing with others:

- Developing cultural understanding 
- Becoming aware of others thoughts and feelings

2. Affective Strategies

a. Lowering your anxiety:

- Using progressive, relaxation, deep breathing or meditation

- Using music

- Using laughter

b. Encouraging yourself

- Making positive statement

- Taking risks wisely

- Rewarding yourself

c. Taking your emotional temperature

- Listening to your body

- Using a checklist

- Writing a language learning diary

- Discussing your feeling with someone else.

Speaking effectiveness include grammatical competence, discourse competence, sociolinguistic competence and strategic competence. The students must consider these four aspects in selecting their suitable learning strategies. And the teacher should introduce the learning strategies based on these four components. The considerations might encourage students not only to master the rule of English grammar but also how to use the rules in a real communication in a variety of contexts.

\section{Techniques in Teaching to Speak English}

Brown provides some principles for designing speaking techniques as follow:

1. Techniques should cover the spectrum of learner needs from language based focus on accuracy to message-based focus on interaction, meaning and fluency.

2. Techniques should be intrinsically motivating.

3. Techniques should encourage the use of authentic language in meaningful contexts. 
4. Provide appropriate feedback and correction

5. Capitalize on the natural link between speaking and listening.

6. Encourage the development of speaking strategies. (Brown, 1987)

It is clearly important for teachers to introduce variety of learning strategies to their students. Some students even do not recognize some other strategies in learning as if they do not have choices.

Richards and Renandya explain some considerations in the form of test of a technique's potential for creating or sustaining intrinsic motivation of which represents a facet of principle of intrinsic motivation (Richards, Jack, 2002). For instance, the technique should appeal to the genuine interests of the students, the technique should be presented in a positive, enthusiastic manner and the students are clearly aware of the purpose of the technique. Furthermore, they add that the teachers should consider whether the technique encourage students to discover for themselves certain principles or rules rather than simply being 'told' and whether it also encourage students in some ways to develop or use effective strategies learning and communication. There are some techniques that can be applied by teachers in teaching their students to speak English, such as role play (with one student-taking the role of a foreigner), naïve-speaker visitor answer questions $\mathrm{n}$ specific topics, pen friends (by mail or e-mail), group presentation, interclass debate, speech competitions, concerts (plays and singing).

\section{Research Methodology}

This research is descriptive which tries to describe and elaborate the students' strategies in learning to speak English and their English teachers' techniques in teaching them to speak English. Descriptive research is a scientific description of an actual phenomenon by explaining one variable to another without describing the relationship among them which can be useful for further research. Gay states that a descriptive study determines and describes the way things are (Gay, 2000). There were two instruments used in this research, the questionnaire and interview guidance. Both instruments were given to the students and the English teachers but consist of different items. The questionnaires had been tried out before they were given $t$ the sample in order to ensure the time consuming in filling them and to provide appropriate information based on the purpose of the research, and also for the improvement of the questionnaire itself. The tried out also used 
to see the validity and the reliability of the instruments (Ary, Donald, 1985). Finally, the data collected were categorized based on the criteria stated by Oxford as follow:

Table 1

The Intensity of Strategies

Used in Learning and Teaching Speaking

\begin{tabular}{|l|l|l|}
\hline \hline Criteria & Frequency & Score \\
\hline \hline Very High & Always & $5,50-5,00$ \\
\hline High & Usually & $3,50-4,49$ \\
\hline Medium & Sometimes & $2,50-3,49$ \\
\hline Low & Rarely & $1,50-2,49$ \\
\hline Very Low & Never & $1,00-1,49$ \\
\hline \hline
\end{tabular}

The score above would place the students and the English teachers to in what level of frequency they are and how often they use the strategies in learning and teaching speaking.

Students' Strategies in learning to Speak English in the Class at School and out Class in Their Daily Life

After giving questionnaire to 55 selected students of SMAN 1 Curup and to 7 English teachers, also doing the interviews and several observations not only in the classroom (during the English teaching and learning process) but also outside the class at school, the finding is presented as in the following table:

Table 2

The Category of Students' Strategies in learning to Speak English

\begin{tabular}{|l|l|l|l|}
\hline \hline No & $\begin{array}{c}\text { Strategies in learning to speak } \\
\text { English }\end{array}$ & Score & \multicolumn{1}{|c|}{ category } \\
\hline \hline 1 & Memorizing words & 3,84 & High \\
\hline 2 & $\begin{array}{l}\text { Pronouncing the specific and } \\
\text { new words }\end{array}$ & 3,72 & High \\
\hline 3 & Practicing Conversation & 3,47 & Medium \\
\hline 4 & $\begin{array}{l}\text { Listening to English } \\
\text { Conversation }\end{array}$ & 3,40 & Medium \\
\hline 5 & Watching English Movie on TV & 3,37 & Medium \\
\hline 6 & Reading English text & 3,31 & Medium \\
\hline 7 & Singing English songs & 3,31 & Medium \\
\hline
\end{tabular}




\begin{tabular}{|l|l|l|l|}
\hline 8 & $\begin{array}{l}\text { Listening to new English word } \\
\text { when someone speaks to me }\end{array}$ & 3,25 & Medium \\
\hline 9 & $\begin{array}{l}\text { Listening to specific grammar } \\
\text { points }\end{array}$ & 3,17 & Medium \\
\hline 10 & Asking question in the class & 3,14 & Medium \\
\hline 11 & Watching English Program on TV & 301 & Medium \\
\hline 12 & $\begin{array}{l}\text { Practicing English with } \\
\text { classmates }\end{array}$ & 2,91 & Medium \\
\hline 13 & Translating English texts & 2,77 & Medium \\
\hline 14 & Playing word games and puzzles & 2,74 & Medium \\
\hline 15 & $\begin{array}{l}\text { Answering teachers' questions in } \\
\text { the class }\end{array}$ & 2,64 & Medium \\
\hline 16 & $\begin{array}{l}\text { Speaking up in a small group n } \\
\text { the class }\end{array}$ & 2,35 & Low \\
\hline 17 & Watching English plays & 2,33 & Low \\
\hline 18 & $\begin{array}{l}\text { Repeating language from an } \\
\text { audiotape }\end{array}$ & 2,33 & Low \\
\hline 19 & $\begin{array}{l}\text { Answering questions in English } \\
\text { outside the class }\end{array}$ & 2,25 & Low \\
\hline 20 & $\begin{array}{l}\text { Raising hand in the class to take } \\
\text { turn to speak in the class }\end{array}$ & 2,20 & Low \\
\hline 21 & $\begin{array}{l}\text { Listening to English news from } \\
\text { the radio }\end{array}$ & 2,11 & Low \\
\hline 22 & Playing drama in English & 2 & Low \\
\hline 23 & $\begin{array}{l}\text { Reading English newspapers and } \\
\text { magazines }\end{array}$ & 1,99 & Low \\
\hline 24 & Speaking with natives & 1,97 & Low \\
\hline 25 & Using internet for chatting & 1,94 & Low \\
\hline 26 & $\begin{array}{l}\text { Phone a friend and speak in } \\
\text { English }\end{array}$ & 1,93 & Low \\
\hline \hline & Most of the students memorize words and practice to pronounce & \\
\hline
\end{tabular}

Most of the students memorize words and practice to pronounce the specific sounds of English words to increase their speaking ability. It indicates that the students do not use appropriate strategies in speaking. However, there are also some other strategies used by the students, such as practicing conversation, listening to English conversations, watching English movie on TV, reading English text, singing English songs, asking questions in the classroom and practicing English with classmates. The result also indicates that using natives to practice English is quite rare for the students. The social strategies were mostly performed unconsciously. Activities such as asking questions (asking 
for clarification or verification) and asking for correction, cooperating with others (peers and proficient users of English) were done as a part of teaching learning activities in teaching and learning process. Even the students did not realize their own strategies. A number of best learners from SMA 1 Curup use affective and social strategies to control their emotions, to stay motivated, to cooperate and to get help.

In other side, this research shows another finding taken from interviews on what strategies that the students used in learning to speak English outclass at school. The finding is presented in the following table:

\section{Table 3}

Students' Strategies in Learning to Speak English Outclass at School

\begin{tabular}{|l|l|l|}
\hline \hline No & Strategies in learning to speak English outclass & $\%$ \\
\hline \hline 1 & $\begin{array}{l}\text { Speaking with friends: } \\
\text { 1. Speaking with friends in daily conversation at } \\
\text { school }\end{array}$ & 25 \\
& $\begin{array}{l}\text { 2. Speaking with friends by using text } \\
\text { 3. Speaking in pairs } \\
\text { 4. Speaking with the English teachers by using } \\
\text { Indonesian and English } \\
\text { 5. Speaking with friends by using English and } \\
\text { Indonesia about simple topics. }\end{array}$ & $\begin{array}{l}7,14 \\
7,14\end{array}$ \\
\hline 2 & $\begin{array}{l}\text { Speaking English by using English dictionary for for } \\
\text { the new words }\end{array}$ & 7,14 \\
\hline 3 & Asking for solution from the teachers and friends & 7,14 \\
\hline 4 & Speaking in front of the class & 3,57 \\
\hline 5 & Speaking what I'm thinking & 3,57 \\
\hline \hline
\end{tabular}

The rest of students answer that they even did not plan to speak English because of their low self confidence and did not master enough English vocabulary to build the utterances. The responses given show that there were only 17 students often speak English with friends outclass at school and realize that always practice to speak English with everybody in school is one of their strategy. Only two students said that they speak with their teachers or friends by using English and Indonesian for the unfamiliar words in order to speak English fluently. 
Another interested findings is the students have more time to use their strategies in learning to speak English outclass in their environment or their daily life. The students' activities out school mostly provide more opportunities not only to practice their ability in speaking English but also to build their self confidence in speaking English itself. The strategies are presented in the following table:

\section{Table 4}

Students' Strategies in Learning to Speak English Out School/Daily Life

\begin{tabular}{|l|l|l|}
\hline \hline No & Strategies in learning to speak English Out School & $\%$ \\
\hline \hline 1 & Taking English Course & 39,29 \\
\hline 2 & Speaking English with friends & 21,43 \\
\hline 3 & Following English Competitions & 7,14 \\
\hline 4 & Speaking English to the mirror & 7,14 \\
\hline 5 & Watching English Films and Imitating the dialogs & 3,57 \\
\hline 6 & Listening to English Music and sing them again & 3,14 \\
\hline \hline
\end{tabular}

The students' responses above show that most of them take English courses out school in learning to speak English. The rest of them did not find suitable strategies for themselves in learning to speak English.

\section{Teachers' Techniques in Teaching Speaking}

After interviewing 7 English teachers of SMAN 1 Curup, and doing some observations not only in the classroom-during the English Teaching and Learning Process-but also in school hours, this research presents the finding as in the following table:

Table 5

Teachers' Techniques in Teaching Speaking

\begin{tabular}{|l|l|l|l|}
\hline \hline \multirow{2}{*}{ No } & Teachers' Techniques & $\%$ \\
\cline { 2 - 2 } & In the classroom & Out Class & \\
\hline \hline 1 & Group Discussion & & 75 \\
\hline 2 & Question Answer in Pairs & & 25 \\
\hline 3 & Debate Competitions & & 25 \\
\hline 4 & Games & & 25 \\
\hline 5 & Singing English Songs & 20 \\
\hline 6 & & Speech Competitions & 25 \\
\hline 7 & & $\begin{array}{l}\text { Greeting about teacher } \\
\text { condition }\end{array}$ & 25 \\
& & & \\
\hline
\end{tabular}




\begin{tabular}{|l|l|l|l|}
\hline 8 & \multicolumn{2}{|l|}{ Recreation } & 25 \\
9 & $\begin{array}{l}\text { Speaking with the } \\
\text { Foreigners }\end{array}$ & 25 \\
\cline { 3 - 4 } & Opening English Course & 25 \\
\hline \hline
\end{tabular}

The findings also show that not all English teachers use English in communicating with the students. This condition limits the students' opportunities to practice English. However, the teachers always motivate their students by providing discussion in the classroom. Teachers' techniques mostly take role out class, such as creating English speech competitions, recreation, and speaking with the foreigners. Unfortunately, not all teachers concern about the strategies used by their students in learning to speak English. Often, the students must find their own strategies without even realize which of those strategies are suitable for them.

\section{CONCLUSION}

Students are different in the way of thinking, perceiving, believing and regarding something. Those differences affect their strategies in learning. There were number of strategies used by the students of SMAN 1 Curup in learning to speak English, they are: speaking with friends, speaking with English teachers, taking English course, practicing dialogs watching movies and singing English songs. In fact, the English teachers did not apply a variety of techniques in the classroom during the teaching and learning process. The teachers provide larger opportunities for the students to speak English out class and out school. It is suggested that the teachers introduce more strategies in learning to speak English to their students through the using of variety of teaching techniques in the classroom and more activities outclass. By knowing more learning strategies, the students will be able to recognize and select the appropriate strategies for themselves in order to improve their ability in speaking English.

\section{REFERENCES}

Ansyar, M. 2003. Competency-Based Education: Some Implications to Language Curriculum. Forum Pendidikan. 28 (03). 327-338.

Ary, D., Jacobs, L.C., dan Razavieh, A. Tanpa tahun. Pengantar Penelitian Pendidikan. Terjemahan ole Arief Fuchan. Surabaya: Usaha Nasional. 
Ary, Donald. 1985. Introduction to Research Education. New York: CBS College Publishing.

Benson, Phill. 2001. Teaching and Researching Autonomy in Language Learning. London: Pearson Education Limited.

Bloomfield, Leonard. 1995. Language. Jakarta: PT Gramedia.

Brown and Yule. 1999. Teaching the Spoken Language. Cambridge: Cambridge University Press.

Brown, D. H. 1987. Principles of Language Learning and Teaching. 2nd Edition. Englewood Cliffs, N.J.: Prentice Hall, Inc.

Brown, G., Malmkjar, K., and Williams, J. 1996. Performance and Competence in Second Language Acquisition. Cambridge: Cambridge University.

Brown, Gillian and George Yule. 1983a. Teaching the spoken Language: An Approach based on the analysis of Conversational English. Cambridge: Cambridge University Press.

Brown, H. Douglas. 1994. Teaching By Principles: An Interactive Approach in Language Pedagogy. New York: Prentice Hall Inc.

Canale, M. 1983. From Communicative Competence to Communicative Language Pedagogy. In Richards, J.C. and R.W. Schmidt, Language and Communication. London: Longman.

Douglas A. 2001. Center for Applied Linguistic. Digest

Gay, L.R. and Peter Airasian. 2000. Educational Research: Competencies for Analysis and Application. New Jersey: Prentice Hall, Inc.

Hadley, Alice Ommagio. 2001. Teaching Language in Context. United States: Heinle and Heinle Thomson.

Harley, Trevor. 1995. The Psychology of Language. Great Britain: Erlbaum Taylor \& Francis.

http://www.ryerson.ca/ mjoppe/Research/DescriptiveResearch.htm, taken on 14 August 2008.

http://www.sil.org//lingulinks/LANGUAGELEARNING/OtherResources /Gu, taken on 2 August 2008.

Janice, C (Ed). Tanpa tahun. Comunicative Competence for Individuals who Use Augmentative and Alternative Communication (AAC): from Research to Effective Practice, (online)

Krashen, S. D. 1982. Principles and Practice in Second Language Acquisition. New York: Pergamon Press Inc. 
Murcia, Marriane Celce. 2001. Teaching English as A Second or Foreign Language. United States: Heinle and Heinle Thomson.

Nunan, D. and Clarice Lamb. 1996. The Self-directed Teacher: Managing the learning process. New York: Cambridge University Press.

Nunan, David., 2000. Language Teaching Methodology. A Textbook for Teachers. Sydney: Longman.

Oxford, R.L., 1990. Language Learning Strategies. New York: Heinle and Heinle Publisher.

Purwanto, Dr. 2002. Profesionalisme Guru. Jurnal Teknodik. VI (10): 93-100.

Qi, Yichu. 2003. A Practical and Effective Way to Enhance the ESL Students' Oral Competence, The Internet TESL Journal, (online), Vol. IX, No. 3, (http://iteslj.org/Techniques/QioralCompetence.html, taken on 14 August 2008).

Richards, Jack. C and Willy Renandya. 2002. Methodology in Language Teaching. An Anthology of Current Practice. Cambridge: Cambridge University Press

Sadtono, E. 2003. The Teachers' Problems in Teaching Cross Culture Understanding to EFL Students in Mandala Surabaya Chatolic University. TEFLIN, (on line), Vol. 14, No. 1,

Samana, A. 1994. Profesionalisme Keguruan. Yogyakarta: Penerbit Kanisius.

Savignon, Sandra J. 1983. Communicative Competence: Theory and Classroom Practice. Menlo Park, California: Addison-Wesley Publishing Company, Inc.

Swann, J, Pugh and Lee (Ed). 1980. Language and Language Use. London: Heineman Educational Books Ltd.

Tarigan, H. G. 1990. Pengajaran Kompetensi Bahasa. Bandung: Angkasa Wibowo, Alexander. J dan Fandy Tjiptono. 2002. Pendidikan Berbasis Kompetensi. Yogyakarta: Universitas Atmajaya.

Widdowson, H. G. 1978. Teaching Language as Communication. Oxford: Oxford University

Zainil. 2003. Language Teaching Methods. Padang: Universitas Negeri Padang Press. 